$10-2016$

\title{
Book Review: Genocide on the Drina River
}

Iva Vukušić

Utrecht University

Follow this and additional works at: https://digitalcommons.usf.edu/gsp

\section{Recommended Citation}

Vukušić, Iva (2016) "Book Review: Genocide on the Drina River," Genocide Studies and Prevention: An International Journal: Vol. 10: Iss. 2: 138-140.

DOI:

http://dx.doi.org/10.5038/1911-9933.10.2.1427

Available at: https://digitalcommons.usf.edu/gsp/vol10/iss2/13

This Book Review is brought to you for free and open access by the Open Access Journals at Digital Commons @ University of South Florida. It has been accepted for inclusion in Genocide Studies and Prevention: An International Journal by an authorized editor of Digital Commons @ University of South Florida. For more information, please contact digitalcommons@usf.edu. 
Book Review: Genocide on the Drina River

\author{
Iva Vukušić \\ Utrecht University \\ Utrecht, The Netherlands
}

Genocide on the Drina River

Edina Bećirević

New Haven and London, Yale University Press, 2014

237 pages; Price: $\$ 65.00$ Hardcover

Iva Vukušić

History Department, Utrecht University, The Netherlands

The violent breakup of the former Yugoslavia, with its most brutal manifestation in Bosnia and Herzegovina (BiH) from 1992 to 1995, has been the subject of sustained scholarly interest for the past two decades. One of the main points of contention and fierce debate has been the issue of genocide: if it has been committed, where, when and by whom. These disagreements are largely the result of scholars applying different understandings of the concept of genocide, where one group of scholars uses the definition from the 1948 United Nations Convention on the Prevention and Punishment of the Crime of Genocide, while others consider that definition, which was subsequently adopted by international criminal tribunals, to be too limited. In this personal account, Edina Bećirević argues that Srebrenica was not the only instance of genocide in $\mathrm{BiH}$ but a "culmination of a planned and widespread genocidal process begun in the spring of 1992 and meant to exterminate Bosnian Muslims throughout the territory of Bosnia and Herzegovina" (p. xii).

The work focuses on seven municipalities of eastern Bosnia, exploring the patterns of mass violence in Zvornik, Vlasenica, Bratunac, Rogatica, Foča, Višegrad, and Srebrenica. Given that the International Criminal Tribunal for the former Yugoslavia (ICTY) in The Hague has prosecuted dozens of individuals for crimes in $\mathrm{BiH}$ since the end of the war, the evidence, testimonies, and judgments have significantly influenced academia, not least because of the incredible amount of documents that are available to researchers in ICTY archives. The author of this book relied extensively on those archives in her research. Another significant case that influenced how the war in $\mathrm{BiH}$ is understood by scholars is the ruling of the International Court of Justice, also in The Hague, in 2007. Both courts, one determining individual responsibility and the other those of states, came to the conclusion that the one incident, i.e. set of events, that qualifies as genocide in the case of $\mathrm{BiH}$ is Srebrenica, in July of 1995, where Bosnian Serb forces over-ran a protected enclave populated mostly by Bosnian Muslims, resulting in mass executions of around eight thousand men and boys. The detained men were locked up in schools and warehouses, sometimes beaten, then killed in summary executions, their bodies scattered in mass graves only to be dug up again in secret, some months later, in an attempt to hide the evidence. The independent scholarly community has, by and large, accepted the rulings and consider Srebrenica to be the 'only' genocide not only in $\mathrm{BiH}$, but in the former Yugoslavia in the 1990s.

In five chapters, Bećirević analyzes the campaign of the violent expulsion of non-Serbs, starting in the spring of 1992, detailing the role of local authorities in putting the campaign in motion. Her analysis provides us with a better understanding of how mass expulsions, dispossession, and detention of thousands and their exposure to torture and inhumane conditions were orchestrated. Significant attention is given to the post-war period, where Bećirević places much attention on the denial of mass atrocities, murder and rape committed by Serb forces during the conflict. The author is a Bosnian native and her book shows an intimate understanding of the communities, which coupled with extensive research of evidence material presented at the ICTY, makes it a valuable contribution to the debate. However, the tone often drifts from scholarly to journalistic and the evidence and analysis do not always sufficiently support her bold claim of genocide in the entire territory of $\mathrm{BiH}$, throughout the war. At times, it seems that the author is more interested in advocacy than a detached scholarly analysis. 
The violent campaign aiming to remove non-Serbs from the territories claimed by the Serb leadership in Croatia and Bosnia and Herzegovina in the early 1990s is largely accepted in scholarship and was described in many works, from James Gow's analysis during the early days of the war, to the recent contributions by Robert Donia. The aim of the campaign was the creation of a homogeneous, contiguous territory populated by Serbs. Those contributions stop short of calling what the Bosnian Serb leadership did, with support from the Belgrade regime and Slobodan Milošević, genocide. Mark Mazower states that the goal of the campaign was not the total extermination of Bosnian Muslims but their removal from the territory and that "ethnic cleansing was an integral part of nation-building, or to be more precise nation-enlarging" for the Bosnian Serb and Serbian authorities. ${ }^{1}$ That view is shared by Dulić and Hall who make a convincing case when stating that Bosnian Serbs made excessive territorial demands, but "did not seek to control the entire country." The Bosnian Serb forces "refrained from capturing municipalities where Serbs constituted a small minority of the population, unless these were of extremely high strategic importance." 2 They continue by saying that "massacre and expulsion were means by which they 'cleansed' territories and thus obtained demographic control over contested space." ${ }^{3}$ War crimes were an essential part of the Serbian strategy in the war, claimed Gow. ${ }^{4}$

Bećirević's contribution seems to suffer from what Christian Axboe Nielsen calls "genocide myopia" in relation to $\mathrm{BiH}$, where any conclusion that a set of crimes committed against non-Serbs was not genocide, be it by a judicial or scholarly authority, is considered flawed. ${ }^{5}$ For Bećirević, crimes against humanity and war crimes are not enough, as if those qualifications are somehow less serious, or less deserving of condemnation. Genocide is a concept that was born out of the advocacy of Raphael Lemkin, and the definition in the 1948 Genocide Convention is a result of negotiations. Much criticism has been leveled at it for not including political groups among those that are considered protected. That definition is limited, and proving that charge in a courtroom has been challenging for prosecutors. Claiming that everyone who subscribes to this definition and thus finds it impossible to accept her argument that genocide has been committed on the entire territory of $\mathrm{BiH}$, from 1992 to 1995, and calling them deniers, as Bećirević does, is wrong and fundamentally unfair. Many of those that accept ICTY and ICJ judgments in calling Srebrenica genocide, but refrain from doing so for other municipalities, have no history of political bias and have spoken out about the violent take-over of municipalities, the mass detentions, the killings and rape committed against non-Serbs.

The approach taken by the author could be more nuanced when she analyzes the relevant actors i.e. those that put the mass violence in motion. Too often, she speaks of 'Serbs' as actors, a homogeneous agent with a homogeneous leadership led by the puppet master Milošević and his allies in $\mathrm{BiH}$. This approach is reductionist and is belied by extensive documentation and evidence presented at the ICTY. Catherine Baker makes a good point when she asks authors to be specific and attribute actions to individuals and institutions instead of groups, "even though it lengthens sentences." 6

Ideology, or nationalism, is emphasized as the main driving force of the violence, and the book makes ample use of historical events which have allegedly primed the Serb communities to separate themselves from others, in this case Bosnian Muslims, and commit genocide. However, it is not clearly explained how those processes allegedly took place. Historical events become myths that are then used to mobilize nationalist sentiment, but as Siniša Malešević rightly argues,

\footnotetext{
${ }^{1}$ Mark Mazower, "Review Essay Violence and the State in the Twentieth Century," The American Historical Review 107 (4) (2002), 1163.

2 Tomislav Dulić and Jonathan Hall, “The logic(s) of ethnic violence: Control, ideology and the spatial distribution of indiscriminate violence in Bosnia and Herzegovina, 1941-45/1992-95" (Unpublished manuscript, Uppsala University, 2014), 5 .

${ }^{3}$ Ibid., 5 .

${ }^{4}$ James Gow, The Serbian Project and its Adversaries: A Strategy of War Crimes (London: C. Hurts \& Co., 2003$), 2$.

${ }^{5}$ Christian Axboe Nielsen, "Surmounting the myopic focus on genocide: the case of the war in Bosnia and Herzegovina," Journal of Genocide Research, 15:1 (2013), 22.

${ }^{6}$ Catherine Baker, The Yugoslav Wars of the 1990s (Palgrave Macmillan, 2015), 3.
} 
nationalism is not inherently violent and more attention should have been given to analyzing how and why that particular nationalism turned violent. ${ }^{7}$ It would have also been interesting to discuss the similarities and differences between state-level elite and local leaderships and their motivations. Dulić and Kostić have argued that ideology has dominated the motivations of the elites, while fear and insecurity played a more significant role at the local level. ${ }^{8}$

In sum, this book is thought-provoking and valuable in the micro analysis of the dynamics of violence and the role of local Bosnian Serb authorities in orchestrating the violence that swept the country in the spring of 1992. However, it has made the mistake of arguing more than it can actually prove. A dreadful machinery of violence that left one hundred thousand dead and over a million displaced was set in motion in early 1992 by Bosnian Serb authorities: it included camps, expulsion, dispossession, mass murder, torture and rape. Not labeling all of those events as genocide does not minimize the experiences of those who suffered through them, or perished. The narrower understanding of genocide, as defined by the UN Convention, and its application to $\mathrm{BiH}$ simply aims to differentiate between types of mass violence. The mass executions after the fall of Srebrenica, in 1995, were indeed unique in their systematic nature and the consequences they had on those communities. Srebrenica can be understood as a culmination of the policies set in place three years earlier, but it should be categorized as distinct-as genocide.

\section{Bibliography}

Baker, Catherine. The Yugoslav Wars of the 1990s. London: Palgrave Macmillan, 2015.

Dulić, Tomislav and Jonathan Hall. "The logic(s) of ethnic violence: Control, ideology and the spatial distribution of indiscriminate violence in Bosnia and Herzegovina, 1941-45/199295". Unpublished manuscript, Uppsala University, 2014.

Dulić, Tomislav and Roland Kostić. "Yugoslavs in Arms: Guerilla Tradition, Total Defense and the Ethnic Security Dilemma." Europe-Asia Studies, 62:7 (2010): 1051-1072. http://dx.doi.org/10 $.1080 / 09668136.2010 .497015$

Gow, James. The Serbian Project and its Adversaries: A Strategy of War Crimes. London: C. Hurst \& Co., 2003.

Malešević, Siniša. “Is Nationalism Intrinsically Violent?." Nationalism and Ethnic Politics, 19:1 (2013): 21-37. http://dx.doi.org/10.1080/13537113.2013.761894

Mazower, Mark. "Review Essay Violence and the State in the Twentieth Century." The American Historical Review, 107 (4) (2002): 1158-1178. http://dx.doi.org/10.1086/532667

Nielsen, Christian Axboe. "Surmounting the myopic focus on genocide: the case of the war in Bosnia and Herzegovina." Journal of Genocide Research, 15:1 (2013): 21-39. http://dx.doi. org/10.1080/14623528.2012.759397

\footnotetext{
${ }^{7}$ Siniša Malešević, "Is Nationalism Intrinsically Violent?," Nationalism and Ethnic Politics, 19:1 (2013), 18.

${ }^{8}$ Tomislav Dulić and Roland Kostić, "Yugoslavs in Arms: Guerilla Tradition, Total Defense and the Ethnic Security Dilemma," Europe-Asia Studies, 62:7 (2010), 1052.
} 